\title{
Transatlantica
}

Revue d'études américaines. American Studies Journal

\section{Ada Savin, L'Amérique par elle-même. Récits autobiographiques d'une Terre Promise, Paris, Michel Houdiard, 2010}

Sofie De Smyter

\section{(2) OpenEdition}

1 Journals

Édition électronique

URL : https://journals.openedition.org/transatlantica/5898

DOI : $10.4000 /$ transatlantica.5898

ISSN : $1765-2766$

Éditeur

Association française d'Etudes Américaines (AFEA)

Référence électronique

Sofie De Smyter, «Ada Savin, L'Amérique par elle-même. Récits autobiographiques d'une Terre Promise Paris, Michel Houdiard, 2010 », Transatlantica [En ligne], 2 | 2012, mis en ligne le 09 mars 2013, consulté le 06 avril 2023. URL : http://journals.openedition.org/transatlantica/5898 ; DOI : https:// doi.org/10.4000/transatlantica.5898

Ce document a été généré automatiquement le 6 avril 2023.

\section{(c) (i) $\odot$}

Creative Commons - Attribution - Pas d'Utilisation Commerciale - Pas de Modification 4.0 International - CC BY-NC-ND 4.0

https://creativecommons.org/licenses/by-nc-nd/4.0/ 


\title{
Ada Savin, L'Amérique par elle-même. Récits autobiographiques d'une Terre Promise, Paris, Michel Houdiard, 2010
}

\author{
Sofie De Smyter
}

1 In L'Amérique par elle-même, Ada Savin examines the intermingling of the Old Testament and the national ideology of the United States by thoroughly analysing a wide variety of autobiographies. Robert Sayre's idea that autobiographies written in the United States offer its readers the autobiography of the United States is put to the test. It is precisely her choice for the intriguing genre of life-writing that makes Savin's work stand out and guarantees an original take on the longstanding connection between the ideology of the promised land as expressed in the old Testament and the ideological, political incorporation of that idea by the American nation.

2 Autobiography itself is a complex genre that has always hovered in the in-between zone between history and literature, and seems therefore ideal to express the border crossing experience that is the migration to a new country, whether that country is felt to be a land of promise in the material or spiritual sense. It seems the genre par excellence to give expression to the struggle between here and there, then and now, and self and other in the migrants' attempts to establish a (renewed) sense of self.

3 The study is divided into six chapters, each of which offers an intriguing and wellresearched take on autobiographies as written by different groups of migrants in different periods of time. Savin is careful to maintain the red thread throughout her work and at all times makes sure to point out both the differences and similarities between the various incorporations of the idea of the United States as the promised land.

4 She starts with the arrival of the English Puritans in what they consider a blank space of new possibilities and the captivity narratives that were written during that period. She pays ample attention to the first bestseller in American literature, Mary 
Rowlandson's captivity narrative and to the double voice that seems to occupy the narrative, which was born out of the confrontation between the self and the Native other.

5 Savin also closely analyses the testimonies of the latter group and pointedly remarks that the writing of self (and its emphasis on the individual) was not a tradition before the arrival of the Europeans. In addition, even though reading between the lines is highly revealing, one always has to take into account that the stories such as the one written by Black Hawk were adapted, translated and manipulated, and that the voice is even more than it is in another narrative, hyper-hybrid.

The same hybridity of voices characterizes most of the narratives written by the many slaves who were transported to the United States. Many of their songs as well as narratives of self-such as the one by Frederick Douglass and William Wells Brown, are pervaded by biblical imagery and the promise of liberation. If Black Hawk's narrative related of the forced exodus away from the territory he and his community occupied, the slave narratives trace the exodus to the north of the United States, which was perceived as their promised land.

7 In the fourth chapter, Savin examines the meaning of the image of the Exodus in the autobiographies of Jewish immigrants such as Mary Antin and Marcus Eli Ravage. Whereas Antin appears "more American than the Americans" in describing the shedding of her old skin, Ravage's experience of the Promised Land is one of disappointment. Eva Hoffman's Lost in Translation as well focuses on experiences of nostalgia and the inability to find a sense of self. Savin convincingly demonstrates how Jewish-American writers of the second half of the twentieth century testify to the demise of the promise being chased.

8 The final two chapters are devoted to, respectively, Mexican and Chinese immigrants to the United States. For its neighbours to the South, the promise held by the United States is not so much a spiritual as a material one, if not that of a simple rite of passage, as in Ramon Pérez' Diary of an Undocumented Immigrant. The latter also holds true for several of the Chinese-American autobiographical works written. These chapters again convincingly testify to the complexity of the experience of migration and the aptness of the autobiographical genre in accommodating its narration.

On the whole, Ada Savin's work is well-researched, fluently written and, as a result, compulsively readable. It does exactly what it promises to do-offer a careful reading of a number of interesting autobiographies rather than propose a theoretical treatise on the genre-and is highly recommendable for anyone interested in the history of the United States as written by the many I's traversing it.

\section{INDEX}

Thèmes : Recensions 
AUTEUR

SOFIE DE SMYTER

University of Leuven (KU Leuven), Belgium 